\title{
Chapter 13 \\ Participatory Research (PR) at CIP with Potato Farming Systems in the Andes: Evolution and Prospects
}

\author{
Oscar Ortiz, Graham Thiele, Rebecca Nelson, and Jeffery W. Bentley
}

\begin{abstract}
Participatory Research (PR) at the International Potato Center (CIP) included seven major experiences. (1) Farmer-back-to-farmer in the 1970s pioneered the idea of working with farmers to identify their needs, propose solutions, and explain the underlying scientific concepts. The ideas were of great influence at CIP and beyond. (2) With integrated pest management (IPM) pilot areas in the early 1990s, entomologists and social scientists developed technologies with farmers in Peru and other countries to control insect pests. Households that adopted just some of the techniques enjoyed high economic returns, and this showed the importance of IPM specialists, social scientists, and farmers working together. (3) Farmer field school (FFS) was adapted for participatory research in the 2000s. Farmers learned that late blight was caused by a microorganism, while testing resistant varieties and fungicides, and researchers took into account more specifically farmer knowledge for training and PR purposes. (4) CIP used participatory varietal selection (PVS) after 2004 to form consortia of farmers, local government, NGOs, and research. Farmers' preferences were disaggregated by gender. Selection criteria of other market actors were included, and new varieties were released, showing the importance of combining farmer and researcher knowledge in this process. (5) Participatory approaches to develop native potato variety value chains. After 2000, CIP used the PMCA (participatory market chain analysis) and stakeholder platforms to improve smallholders' access to markets. PMCA brought farmers and other market actors together to form stakeholder platforms which created market innovations, including
\end{abstract}

\author{
O. Ortiz (凶) \\ International Potato Center, Lima, Peru \\ e-mail: o.ortiz@cgiar.org \\ G. Thiele \\ CGIAR Research Program on Roots, Tubers and Bananas, Lima, Peru \\ e-mail: g.thiele@cgiar.org \\ R. Nelson \\ Cornell University, Ithaca, NY, USA \\ e-mail: rjn7@cornell.edu \\ J. W. Bentley \\ Independent Consultant, Cochabamba, Bolivia
}


new potato-based products, expanding the inclusion of diverse actors in the PR processes. (6) Advocacy for PR and policy change with the Andean Change Alliance tested PR methods including PVS and PMCA from 2007 to 2010, providing evidence to influence policies to include smallholders in research and development. (7) After 2010, nutrition-related PR documented anemia among children in the high Andes, which could be mitigated by eating native potatoes rich in zinc and iron. CIP partnered with 20 organizations to improve household incomes and nutrition. Over four decades, CIP continues evolving in using PR, showing that combining social and biological scientists' input and keeping farmers' views upfront was key for PR. The experience also showed that the participation of other actors related to the value chains was needed in order to create successful agronomic, market, and social innovations. Future participatory research at CIP may be improved by using ICT to enrich diversity and richness of information sharing among PR actors.

\subsection{Introduction}

Spanning nearly 40 years, PR at CIP covered most major areas of agricultural research, including new seed and storage technologies, integrated management of pests and diseases, plant breeding, in situ conservation of genetic resources, and value chains. Participatory research at CIP influenced academic and applied research at many other institutions. CIP played a pioneering role in PR in the 1970s. Since then, PR has waxed and waned (Thiele et al. 2001) and moved to higher levels of scale from farm-level management to value chains, food systems, and policy. This chapter provides an update, focusing on work in the Andes, where several PR experiences took place.

The following case studies of PR at CIP are organized roughly chronologically (although some methods overlapped in time). They start with farmer-back-tofarmer, and continue through IPM pilot units, participatory variety selection, FFS, participatory approaches for native potato variety value chains using the participatory market chain analysis (PMCA), advocacy for PR and policy change (via the Alliance for Andean Change), ending with nutrition-related PR in more recent years.

\subsection{Cases of Potato-Related PR in the Andes: Learning from Experience}

\subsubsection{The Farmer-Back-to-Farmer Model}

The farmer-back-to-farmer model emerged from an interdisciplinary CIP team that included both social and biophysical researchers. CIP's first director, Richard Sawyer, hired anthropologists and expected them to work in an integrated team with the center's breeders and agronomists. The combination of different views amongst 
the scientist around seed potato storage led to the farmer-back-to-farmer model (Rhoades and Booth 1982). This model, with its insistence at looking at actual farmer practice in a pragmatic way, was a major influence on much of the farmer participatory research that would follow at CIP and elsewhere. In many ways farmer-back-to-farmer was ahead of its time.

In the late 1970s, a team of CIP researchers was studying post-harvest losses of potato in the Mantaro Valley of Peru. CIP started its participatory research in the Mantaro Valley because it was then one of Peru's main potato producing areas and one of the nearest to the main market in Lima. CIP anthropologist Robert Werge, and CIP biological scientist Robert Booth and other researchers were developing technology that farmers could use to avoid post-harvest losses, working within the framework of Farming Systems Research (FSR, which later would be largely replaced by farmer participatory research). FSR encouraged researchers from different disciplines to work together, and in their seminal paper, Rhoades and Booth (1982) noted that interdisciplinary research could easily become merely multidisciplinary, with researchers working alone within their disciplinary boundaries, and seldom interacting. Their paper was as much about getting social scientists to work with other researchers as it was about involving farmers.

In the 1970s interaction between anthropologists, economists, and biological scientists often provoked stressful but constructive arguments (Rhoades et al. 1986). Two teams were working from different perspectives, a production team with agronomists and an economist, and a post-harvest team with agronomists and an anthropologist (Thiele et al. 2001). An early breakthrough in the Mantaro Valley potato research came when the anthropologist told the biologists that post-harvest potato losses were really of little concern to farmers, who could use the smaller tubers for seed or for animal feed. Even damaged potatoes could be salvaged for the cooking pot and shriveled tubers could be made into chuño- the Andean method for freeze-drying at high altitudes. However, seed potatoes grow long sprouts that farmers disliked having to break off before planting.

Now it was the biologist's turn to be helpful. Booth explaining to the anthropologist (Werge) that the long sprouts were induced by the darkness where the potatoes were stored, inside the farm houses, and that while seed potato needs to be sprouted, the shorter sprouts were more vigorous than longer ones. This insight helped the anthropologist to refine his questions. By working together, the biologist and the anthropologist refined their problem topic. The issue was no longer post-harvest losses, but how best to store seed potatoes on-farm.

On the Santa Ana research station in the Mantaro Valley, the biologist showed the anthropologist how potatoes stored in diffused light (not in total darkness) developed short vigorous sprouts and a greenish skin. Such tubers were ideal for planting. The anthropologist then took some of the wooden greening trays from the station to the homes of some collaborating farmers and stacked the trays under the porch roof and tried storing seed potato there, in diffused light.

Farmers liked the seed tubers with short sprouts, but observed that the fine wooden trays would be too expensive, so a CIP technologist made some simple racks from local lumber. CIP soon began teaching diffused light storage (DLS) to 
farmers in the Philippines (where Booth was now working) and in Peru, teaching farmers how to make and stack wooden seed trays, but also explaining the underlying scientific principle that potato sprouts are shorter and more vigorous, increasing yield if seed is stored in diffused light.

This experience with DLS became the foundation story for farmer-back-tofarmer, a four-step model. Step 1: the anthropologist and the biologist go to the field to understand the problem from the farmer's perspective based on observation and action research, and to reach a common definition of the research problem (e.g. how to improve the storage of seed potatoes). In steps 2 and 3, the researchers develop a technology through a mix of on-farm and on-station research. Finally, the researchers present a prototype technology to farmers who act as advisors on how to adapt it to suit their own conditions (Rhoades and Booth 1982).

CIP economist Douglas Horton later wrote that the greatest benefit of the Mantaro Valley Project was not improved potato production, but institutional change: within a few years CIP was conducting research in various countries with national programs, based on farmer-back-to-farmer (Horton 1986). While Rhoades and Booth never mention the word "participation" in their 1982 paper, farmer-backto-farmer influenced much of the farmer participatory research (FPR) that would follow (Veteto and Crane 2014). Thirty-five years after it was published, the short, engaging farmer-back-to farmer paper can still be read profitably for its practical philosophy of working with farmers.

Rhoades and Booth (1982) came up with several ideas that still guide much of participatory research. Researchers must work with farmers to identify the right problem to solve, interact creatively with them, work on-farm and on-station, and present the results back to farmers for feedback. Rhoades and Booth understood the importance of telling farmers the underlying principles (why the technology works) and not just how to use it, making it easier for farmers to adapt the technique to their own circumstances. All of these ideas are as sound now as when they were written. A decade later, farmer-back-to-farmer was one of the influences on interdisciplinary participatory research at CIP, but by the 1990s, these research methods were becoming more formal.

\subsubsection{IPM Pilot Areas}

In the early 1990s CIP entomologist Fausto Cisneros led research that included biological scientists and members of the Social Sciences Department, such as Oscar Ortiz an agronomist with specialization in agricultural extension. They studied the Andean potato weevil and how to control it in 15 pilot areas, mostly in Peru, and also in Ecuador, Bolivia, and Colombia. There was also research on the potato tuber moth at six sites (in Peru, Colombia, Bolivia, and the Dominican Republic), and on the sweetpotato weevil in Cuba and the Dominican Republic. Researchers needed to adapt IPM (integrated pest management) to the local conditions (farming practices) and farmers' knowledge in pilot communities, called pilot areas. In those 
communities, researchers would select the most appropriate technologies, and assess farmer knowledge so that training could be provided according to knowledge gaps using practical demonstrations (Cisneros et al. 1995). The technologies were based on the results of previous research conducted by CIP in the late 1980s with Peru's national agricultural research institute, INIA. Through this pioneering experience CIP started working with nongovernmental organizations (NGOs) that were oriented to agricultural extension and development in some of the pilot units (Ortiz et al. 2009).

The researchers realized that each of the IPM technologies had to be validated through participatory research, akin to step 4 of the farmer-back-to-farmer model, presenting results back to communities for advice. The consultation with farmers was held in formal pilot areas ${ }^{1}$ and pilot units ${ }^{2}$ (see definitions below) in five countries. An agronomist was stationed in each pilot area to mentor the farmers on the technologies, to see which technologies worked and to get an idea of how to explain the innovations to other farmers (Cisneros et al. 1995).

This integrated pest management (IPM) research aimed to lower costs, manage pests, reduce environmental damage, and minimize health risks. The key word was "integrated," using many techniques, especially natural enemies, cultural practices, and pheromones. Insecticides were to be used as a last resort, and as little as possible. However, the researchers also realized that IPM had been vaguely described; abstractions would not convince farmers who needed concrete results (Cisneros et al. 1995). Therefore, specific training techniques were developed to support farmers' learning of complex concepts related to IPM (Ortiz et al. 1997).

The pilot area work came after some celebrated IPM research by IRRI with the rice planthopper in Indonesia. However, farmers could manage the planthopper largely by avoiding insecticide and letting natural enemies control the pest (see Heong et al. 2014). In contrast, the Andean potato weevil was becoming a more serious pest largely because of increased intensity of cropping (Ortiz 2006; Parsa 2010). The Andean potato weevil was a difficult pest that needed to be managed with several proactive and preventive options; it was not enough to abandon insecticides and let nature take its course. And, the approach was called "pilot areas" to refer to the communities where the research took place, because for the IPM to work, it needed to be applied in most of or the entire the community for it to work.

The pilot area work was led by an entomologist or an agronomist with experience in pest management who collaborated with a social scientist on training and impact assessment, testing various management options in many pilot areas, for three problems (Andean potato weevil, tuber moth, and sweetpotato weevil). The Andean potato weevil technologies were based on an understanding of local knowledge and on the pest behavior. Andean farmers recognized the adult weevil, and its grub, but did not understand that there were four life stages of the same species (from egg to adult). Entomologists had learned that the Andean potato weevil ate

\footnotetext{
${ }^{1}$ Communities where CIP and collaborators carried out the participatory research.

${ }^{2}$ Portions of farmer's fields where the management options were tested.
} 
only potato, and that the insect could be killed in different stages (egg, larva, pupa, and adult) depending on the season of the year. Technologies included hand-picking adult weevils at night (the adult insect had nocturnal habits), uprooting the volunteer plants that harbored weevils, winter plowing to destroy pupae in the soil, piling potatoes on sheets so the larvae could not pupate in the soil, and making barriers around the field to keep the flightless weevils from walking in from neighboring plots (Cisneros et al. 1995; Ortiz et al. 2009).

Farmers rejected some technologies, including early harvesting and eliminating volunteer plants. But pilot farmers adopted barriers around the fields and piling potatoes on sheets. To teach the technologies chosen by pilot farmers, extensionists designed their own materials, including field visits, dramas, games, and manuals. The most acceptable technologies were then shared with other communities as part of a USAID-funded project, MIPANDES, implemented by the international NGO CARE with technical support from CIP (Cisneros et al. 1995; Ortiz et al. 2009).

Rhoades (1987) had claimed that only $2 \%$ of farmers surveyed had adopted DLS as it was taught, but that the other $98 \%$ had adopted the underlying principles. This may have struck the entomologists as imprecise thinking, and they wanted a more objective way of measuring adoption. Yet, the pilot areas research was designed to give farmers a hand in selecting and rejecting technologies. Farmers could also choose technologies from an integrated menu. Researchers never expected farmers to adopt all of the technologies. However, because so many techniques were taught, it was hard to decide how many components had to be adopted to count as "adoption of IPM" (Ortiz et al. 2009).

Early results showed that adopting even some of the management options led to a large reduction in pest damage. For example, in the pilot area of Huatata, Peru, weevil damage had gone from 44 to $8.5 \%$ in just 4 years. Mizque, Bolivia had a favorable environment for weevils, which damaged all of the tubers before the project, but only $10 \%$ in later years. Results from other pilot areas were comparable. Using even some of the technologies managed the pest (Cisneros et al. 1995).

Therefore, the team opted to study adoption by measuring the economic impact of the technologies. It did not matter how many technologies farmers managed, but the value of the harvest saved by using them. Farmers who adopted some of the IPM practices could achieve an average benefit of about $\$ 100$ per hectare (Ortiz et al. 2009). The pilot areas ended with a large project (MIPANDES) implemented with the NGO CARE in 1995 and 1996 in Cajamarca and three other provinces of Peru to teach farmers the menu of IPM technologies for managing the Andean potato weevil and the tuber moth (Chiri et al. 1997).

The pilot areas work was an important formative experience for the FFS experience which followed it (see Sect. 13.2.3 below), particularly because several of the biological and social scientists who participated in one experience continued with the FFS, and they had realized the importance of farmer learning for IPM and the need for appropriate teaching methods (Ortiz et al. 1997). The pilot areas research proposed a systematic way of validating technologies with farmers and an objective method of measuring the results, yet this method probably did not receive all of the recognition that it deserved because there were limited journal publications. The 
most influential participatory methods tend to be the ones that are well documented. CIP's later research with FFS was well-documented and frequently cited, eclipsing the effort with pilot areas.

\subsubsection{Participatory Research and Training: The FFS Experience}

Following the pilot areas experience, some of the same researchers continued with IPM, but this time with a potato disease, late blight, and a new method of participatory research: FFS (farmer field school). By 1997, plant pathologist Rebecca Nelson had recently transferred to CIP from IRRI, which had been working with FFS since 1987, first with rice planthoppers and rice stemborers in Indonesia, and later with rice blast in Vietnam (Nelson et al. 2001). For the CIP team, FFS made sense because they had already experienced the importance of facilitating farmers' learning of complex concepts involved in IPM, which were even more complex when dealing with the pathogen that causes potato late blight.

IRRI entomologists had explicitly conceived of FFS as an extension method, not for research (Kevin Gallagher, pers. com.) But FFS was based on experiential learning and the learning field so it did have an informal experimental content. FFS at CIP went several steps further (perhaps too many steps, as the research design was often too complicated for farmers). In 1997, FFS became a PR method (Thiele et al. 2001) as Nelson and colleagues redesigned FFS as a research method dubbed FPRFFS (farmer participatory research through farmer field schools).

The IPM pilot areas had worked in 16 sites from Bolivia to Cuba (see previous section) between 1990 and 1996, and the FPR-FFS started in four communities, in a single municipality, in San Miguel, Cajamarca, Peru. Two years later field schools would expand to about 20; and a similar experience took place in Cochabamba, Bolivia. CIP was still partnering with CARE, which had already worked in San Miguel during several projects, including MIPANDES and one called ANDINO, which had taught farmers about late blight (Godtland et al. 2004). The experience later expanded, between 1999 and 2004, to other communities in Peru, and also in Bolivia, Ethiopia, Uganda, China, and Bangladesh with a similar approach through an IFAD-funded project (Ortiz et al. 2011).

In the FFS, farmers observed pest ecology in the field. Farmers studied late blight lesions under small microscopes and cultured the disease in plastic bags to watch its spread (Nelson et al. 2001). Farmers had not previously known that late blight was caused by a microorganism. But the FFS provided also the opportunity to test advanced potato clones with resistance to late blight, something that had effects easily perceived by farmers (Figs. 13.1, 13.2, and 13.3 show different stages of participatory evaluation of potato clones as part of FFS implementation), so that they could select those materials that were suitable for their conditions and preferences (Ortiz et al. 2004). 
Fig. 13.1 FFS participant evaluating potato varieties during flowering in Cajamarca, Peru (2004) (Credits: O. Ortiz)

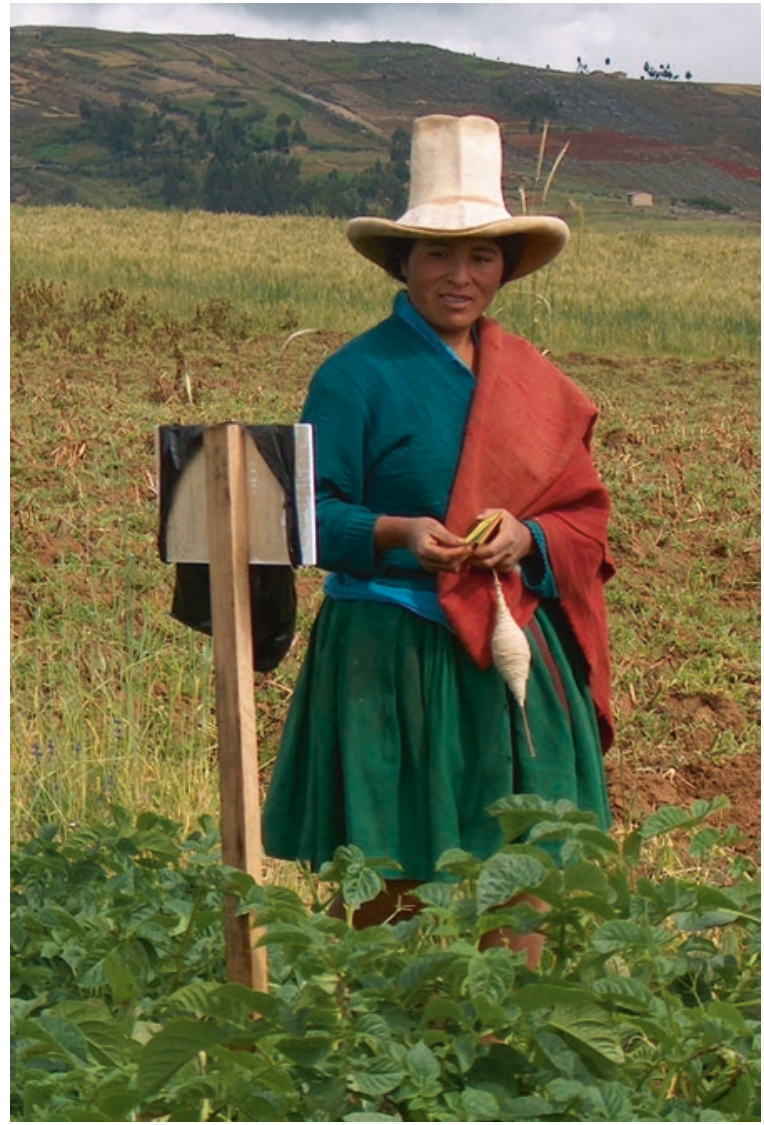

The Indonesian FFS focusing on insect pest management used the simplest possible design: an IPM plot next to a farmer's plot. The late blight FPR-FFS tested three potato varieties, ranging in resistance to late blight. Each variety was treated with fungicide at three different intervals, for a total of nine treatments. This research would show that late blight could be managed through varietal resistance combined with a fungicide regime that was adjusted based on the variety and the environment (Sherwood et al. 2000).

Some farmers seem to have felt that 1 year of field school was enough. The second season, 1998-1999, two of the four communities dropped out of FPR-FFS, but CIP and CARE replaced them with eight new communities. The second year these ten communities replicated their experiment with the potato varieties and fungicides from the previous year (Sherwood et al. 2000).

FPR-FFS was small-scale for its first 2 years, but after that the Dutch government funded a large IPM project with the Andean field schools, led by the FAO (Nelson et al. 2001). Between the second and third seasons of FPR-FFS, 35 extensionists 
Fig. 13.2 FFS farmer during variety evaluation at harvest in Cajamarca, Peru (2003) (Credits: R. Orrego)

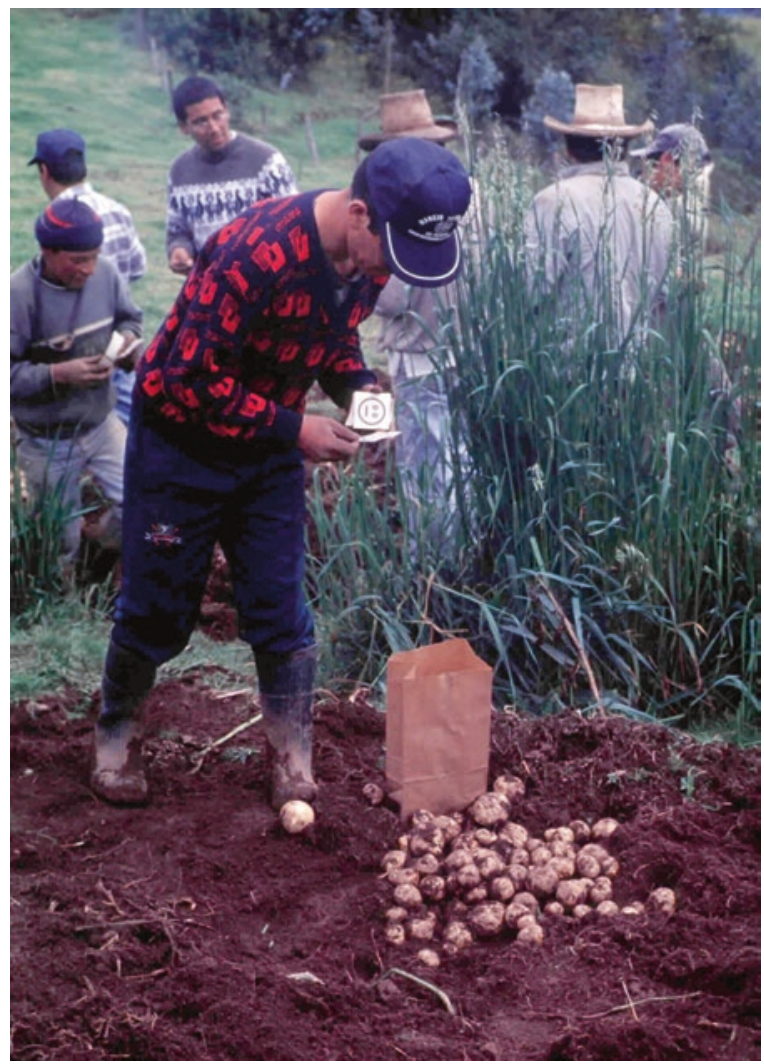

from Peru, Bolivia, and Ecuador attended a 3-month practical ToT (training-oftrainers) FFS course in Ecuador (Sherwood et al. 2000).

After the ToT course, some of the returning extensionists taught the third year of FPR-FFS in San Miguel. It was expanded to 19 communities and three new experiments were added. Farmers continued doing trials of varieties and fungicides. Second, they also tried an IPM vs. farmer's treatment (per the original FFS design), plus a third experiment to grow potatoes from true seed (Nelson et al. 2001). In the fourth experiment, the field schools tested 50 breeding lines of potatoes from CIP. Each community tested just some of the lines, but each clone was tried by two or three communities. This was in 1999-2000, and it foreshadowed the mother-andbaby trials which would be CIP's next participatory method (see following section). Based in part on these evaluations with farmers, one of the varieties (Chata Roja) would be released in 2000 (Nelson et al. 2001).

By now the work with FPR-FFS seemed to be paying off. An economic evaluation showed that late blight management, because of its direct effect on increasing yield, was worth a net benefit of some $\$ 236$ per hectare and year for the farmers of San Miguel (Ortiz et al. 2004). There was also strong implementation of CIPaffiliated field schools in Ecuador, which generated more learning material than 
Fig. 13.3 FFS farmer assessing culinary quality of potato varieties in Cajamarca, Peru (2005) (Credits: O. Ortiz)

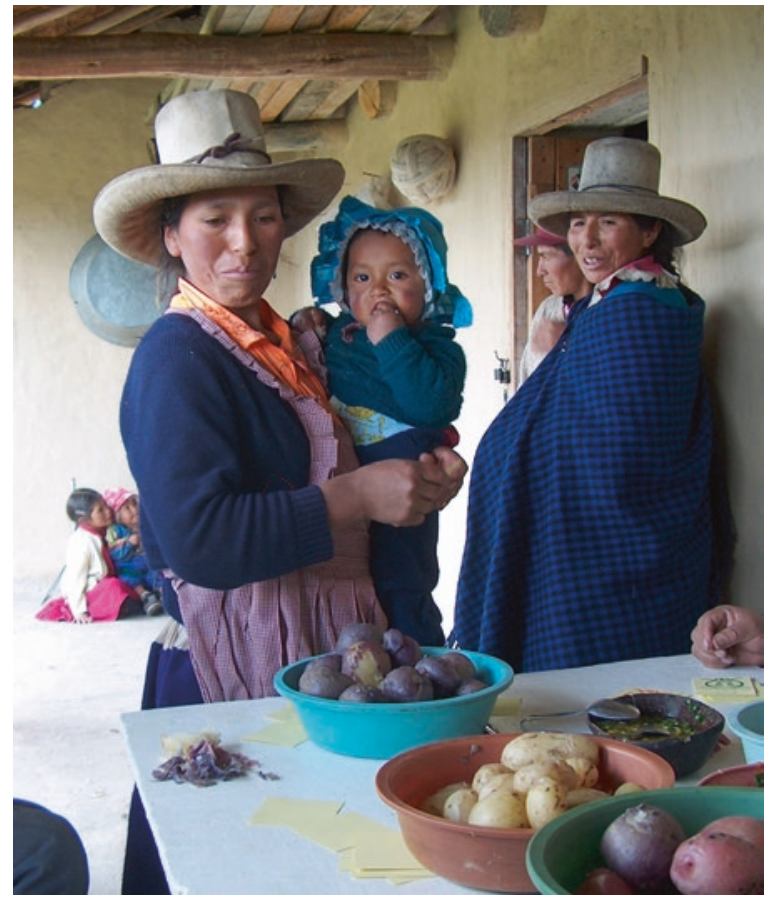

could be covered in a single season; the material was compiled as a manual so that trainers could choose from it to custom-design FFS for other communities (Pumisacho and Sherwood 2000). CIP and other organizations were using FFS in other departments of Peru for bacterial wilt, insect pests, and other topics, but the method was also used in Bolivia, Ecuador, Ethiopia, and Uganda (Ortiz et al. 2008). In 2017 the IPM Association in the US gave the IPM Team Award to CIP and partners for their pioneering work with FFS research for the integrated management late blight, addressing the human and technical components of this technology (Ortiz et al. 2019).

However, CIP's research also looked at the factors that limited farmers' involvement in participatory research through FFS, and CIP observed that "the experimental designs tested sometimes were found to be overly complex for training of farmers" (Ortiz et al. 2004). There was also concern over the costs of FFS, as much as $\$ 1000$ per one FFS per season (Ortiz et al. 2011). Farmers joined the field school to learn, but were discouraged by the time demands; organizations were limited by the lack of qualified trainers (Ortiz et al. 2011). CIP did not continue using FFS as a PR method after 2008, but the method has continued its evolution, and was institutionalized in several public and private agricultural organizations in Peru reaching more than 1000 up to 2008 (Orrego et al. 2010), something that has continued to evolve. More recently, the Peruvian Ministry of Education officially formalized a training and certification program for FFS facilitators (Sineace 2016). 


\subsubsection{Participatory Variety Selection (PVS)}

Plant breeding may take 10 or 12 years or longer to produce a new crop variety. This enormous investment of time, money, and energy can be wasted if the new variety is not adopted. Plant breeders can anticipate farmers' preference for varieties by learning which traits farmers (and consumers) want. For example, there is no point in breeding for processing quality when farmers prefer varieties for table consumption.

In 1987-1988, a Peruvian government project was collaborating with CIP to test varieties with farmers. CIP anthropologist Gordon Prain and agronomist Urs Scheidegger had helped to set this up. Their method was heavily influenced by farmer-back-to-farmer; collaborating farmers were invited to evaluate eight or nine clones, as they saw fit, to find "friendly" varieties. Direct sales of seed to farmer collaborators were seen as an indicator of acceptance (Thiele et al. 2001).

Then Sieglinde Snapp, an agronomist at ICRISAT (International Crops Research Institute for the Semi-Arid Tropics), visited CIP/Lima to share her experiences with a new method of PVS called the mother-and-baby trial design (MBT; Snapp 1999). The MBT method, also known as the central/satellite design, involves a complete, replicated trial in a central location in a community, with satellite mini-trials in farmers' fields. Each farmer trial only includes a subset of the treatments of the central trial, with different farmers testing different combinations of lines such that all the material in the central trial is tested on multiple farms. This visit influenced the types of experiments implemented with the CIP version of FFS. Since plant breeders needed more replicability and numbers for statistical analysis, this MBT method was considered a useful advance. The PVS model thus gave way to an MBT approach, allowing the breeder to collect quantitative, replicated data from the mother trial, while gauging farmers' reactions to the lines or clones grown under farm conditions. The method was widely used at CIMMYT and elsewhere as well (Snapp 2002).

By 1999 CIP had 110 clones of a new breeding group called B1C5, which contained genes from native Solanum tuberosum spp andigena potatoes. The clones combined traits like high yield and resistance to late blight with tolerance for low inputs, early maturity (120 days instead of 180) and the taste qualities that Andean consumers preferred (Allauca 2011; Janampa 2012; Camacho-Henriquez et al. 2015). In 2004, CIP plant breeders sent 20-30 advanced clones to communities in Cusco in the high Andes. Over the subsequent decade, CIP facilitated the formation of a consortium of farm communities, municipalities, NGOs, universities, and INIA-Peru's national agricultural research agency so use PVS, and trained key members of staff to use the MBT method (Camacho-Henriquez et al. 2015).

Mother and baby trials were evaluated by the farmers who grew them, but also by other community members who met three times during the season (flowering, harvest, and post-harvest). Farmers' selection criteria were free-listed and then prioritized, giving villagers maximum flexibility to define the traits that they demanded. Women and men farmers worked in separate groups so that the results could be 
disaggregated by gender. At harvest, the yields were measured and farmers evaluated the potatoes by appearance, taste, and texture. Farmers evaluated the potatoes at post-harvest for weight loss, dormancy, and sprouting. The mother-and-baby trials were gender sensitive and appropriate for illiterate farmers (Camacho-Henriquez et al. 2015).

In 2007, as a result of the mother and baby trials, several potato varieties were released in Peru, including Pallay Poncho, Puca Lliclla, Altiplano (Arcos et al. 2015), and Kawsay (Camacho-Henriquez et al. 2015) followed by others later, e.g. INIA 325-Poderosa (CIP 2014). Some farmers in participating communities even set up businesses to produce and sell seed of the new varieties (Camacho-Henriquez et al. 2015).

In 2008-2009, as part of the Cambio Andino Program, CIP established further trials with four consortia ( three places per consortium, with 10-20 clones at each site. In each region, each consortium had a leader (an NGO or another organization) that facilitated the mother-and-baby trials. By the third year (2010-2011) three clones were selected at each cite (Fonseca et al. 2011). CIP held annual workshops with the consortia members to improve the mother-and-baby method (Fonseca et al. 2011).

The mother-and-baby trial design allowed plant breeders to understand farmers' selection criteria (e.g. large tubers, resistance to frost and to late blight). There were some gender differences, with women preferring potatoes for boiling. MBT allowed farmers to receive the varieties they wanted. Participation with food manufacturers, wholesalers, and restaurants allowed selecting potatoes that met market demand (Fonseca et al. 2011); this foreshadowed methods CIP would pioneer later to engage with other market actors, besides farmers.

In order to improve the quality and standardization of the mother-and-baby method CIP published a manual to describe it in detail for trainers and facilitators (de Haan et al. 2017). MBT was originally designed to be used by plant breeders and farmers. By adding government, private sector, NGOs, vocational schools, and other actors, CIP was able to involve representative of the whole value chain in selecting varieties. This helped not just to select desired traits, but to facilitate registration of new varieties and to disseminate them with farmers, buyers, processors, and consumers. PVS at CIP went beyond the mother-and-baby approach and also combined participatory approaches with online data collection and analysis tools, which was another innovation in participatory research.

\subsubsection{Participatory Development of Native Variety Value Chains}

An analysis of different market opportunities revealed that innovation in selling native potatoes had the greatest potential to improve the incomes of smallholders in the high Andes (Devaux et al. 2009). During the 1990s, the road network expanded 
dramatically in Peru, allowing trucks to reach remote areas previously unreachable, and lowering transportation costs for potatoes and other produce. With long-term support from the Swiss Development Cooperation, CIP began a decade of addressing market opportunities for the native potato, developing and using two tools: the PMCA (participatory market chain analysis) and stakeholder platforms (Devaux et al. 2009). CIP researchers Thomas Bernet, André Devaux, Graham Thiele, and others created the PMCA in 2000 (Bernet et al. 2006), based on RAAKS (rapid appraisal of agricultural knowledge systems - see Engel and Salomon 2003). In the early 2000s, PMCAs conducted with support from CIP started to address the question of how to improve smallholders' access to markets, especially for farmers cultivating potato landraces. One key bottleneck was that native potatoes were unfamiliar to consumers of Lima, Peru's capital and largest city. Through its work with gastronomy schools, the PMCA helped Peruvian chefs to appreciate the culinary potential of native potatoes. This gave native potatoes a new image; and they were now acceptable to middle-class consumers (Horton and Samanamud 2013).

A single PMCA can last for 2 years and comprises three phases. Phase one includes a market survey to identify the stakeholders and includes a large meeting that brings stakeholders together in one room (Devaux et al. 2009). While previous participatory research engaged with researchers, extensionists and farmers, the PMCA links with many more actors (including ministry officials, market specialists, food technologists, transporters and wholesalers, food processors, supermarkets, and chefs-Ordinola et al. 2014). The event must be expertly facilitated to form a community from actors who all work in the same value chain, but many of whom have never met for co-innovation (Devaux et al. 2009).

At this first event, the facilitator helps processors (e.g. supermarkets and food manufacturers) to present a diagnosis and set up groups on promising possible innovations. By the end of Phase 3, innovations move to the promotion phase. In Peru, the PMCA stimulated the following innovations: colored potato chips, made from native varieties, tunta and chuño, clean and well sorted in small bags, and fresh potatoes of native varieties in net bags for supermarkets (Devaux et al. 2009).

At the start of the PMCA in Peru, and as part of the Papa Andina project, the team used what they called a "pro-poor filter," to identify market segments where resource-poor farmers would be especially likely to benefit. This led to the selection of native potatoes produced in the high Andes mostly by resource-poor farmers, as an attractive market segment for innovation. In Peru, multinational companies dominated much of the market for conventional potato chips from improved potatoes supplied by larger producers.

During the second phase of the PMCA, different actors begin to work together, researching and developing different innovations (which could be commercial products or institutional innovations, such as multi-stakeholder platforms). The third phase sees these innovations finished and ends with a large, final event where companies, farmers, and others come together to launch the new products and other innovations. It is important that the companies own the new brands. For example, Wong Supermarket created a brand, T'ikapapa, of mixed, colorful native potato 
varieties in an attractive net bag, as an outcome of the PMCA (Thiele et al. 2011; Devaux et al. 2009).

As the actors of the value chain begin to work together, buying and selling their products, they learn to trust each other which can lead them to take collective actions, such as Peru's National Potato Day, celebrated on 30 May every year since 2005 with displays of native varieties and gourmet food (Horton and Samanamud 2013; Ordinola et al. 2014). This achievement led the stakeholders, via the Ministry of Agriculture, to successfully petition the UN to name 2008 as the International Year of the Potato (Horton and Samanamud 2013). A new stakeholders' platform emerged from the PMCA to advocate for native potatoes and to consolidate their market position (Devaux et al. 2009; Thiele et al. 2011).

Creating products from native potatoes allowed smaller processors to open a niche market for smallholders, at a price 10-30\% higher than before (Devaux et al. 2009). For example, Jalca Chips, which was directly influenced by PMCA, innovated by selling colored potato chips made from native varieties, at the Lima International Airport. This triggered other innovation processes as PMCA intended with the chips have since been copied and improved upon by other food manufacturers and are now widely sold in Peru under various brand names.

An important outcome of the PMCA in Peru was the inclusion of native varieties in the National Registry of Commercial Cultivars (Horton and Samanamud 2013). This allows native varieties to be legally sold as seed and is an important step in their continued survival.

The PMCA stimulated a broader innovation process. In Peru, the wholesale price of native potatoes is increasing as is the volume sold (Horton and Samanamud 2013). The smallholders who supply these native potatoes benefit from higher prices, so that the PMCA has many more indirect beneficiaries than direct ones (Ordinola et al. 2014).

CIP replicated the PMCA with partners in Bolivia (Proinpa) and Ecuador (INIAP). Bolivia also experienced a revived interest in native crops. The PMCA fostered the creation of bagged and clean chuño, native potato chips and net bags of fresh native potatoes sold in supermarkets (Thiele et al. 2011; Oros et al. 2011).

The PMCA stimulated the creation of stakeholder platforms as an institutional innovation. In Ecuador, the potato stakeholder platform triggered the creation of an organization, the Consortium of Small Potato Producers (CONPAPA) which linked highland farmers to others who produce quality seed and bulked potatoes for sale so smallholders can consistently supply the market for modern varieties with a high commercial demand (Thiele et al. 2011; Devaux et al. 2009; Kromann et al. 2016).

Participatory research started at CIP triggered by the interaction of social scientists and agronomists as described earlier around seed systems. Over the years, researchers learned to collaborate with farmers across a broader range of useful technologies including varieties. But PMCA and stakeholder platforms went one step further, involving the other actors of the value chain to explicitly demand new research and launch new commercial products. Farmers responded eagerly to the new market demands for native potatoes (Thiele et al. 2011). 


\subsubsection{Advocacy for PR and Policy Change (Experience of Cambio Andino)}

From 2007 to 2010 a project managed by Graham Thiele at CIP and Carlos Arturo Quirós at CIAT, called Andean Change Alliance (Alianza Cambio Andino, in Spanish), partnered with a broad group of about 20 public and civil organizations, including Proinpa (Promotion and Research for Andean Products) in Bolivia, INIAP (National Agricultural and Livestock Research Institute in Ecuador), INCOPA (a CIP-led project for Innovation and Competitiveness of the Potato) in Peru, the PBA Foundation in Colombia, and many others to advocate for participatory research by showing that participatory methods enhanced research outcomes and helped give the poor a voice to ensure their demands were attended to (Thiele et al. 2012). In Colombia, Ecuador, Peru, and Bolivia, the Alliance tested various participatory methods including: Participatory Monitoring and Evaluation (SEP), Local Committees for Agricultural Research (CIALs), Participatory Variety Selection (see Sect. 13.2.4), and PMCA (Thiele et al. 2012).

To build an evidence base for advocacy for participatory research, the Andean Change Alliance developed a knowledge bank, including an online catalog of participatory methods (www.cambioandino.org) and a book of case studies (Thiele et al. 2012). The Andean Change Alliance was broad ranging including NGOs, universities, farmer associations, local and national governments of Peru, Bolivia, Ecuador, and Colombia. Advocacy was systematically and sequentially organized identifying both "pain points" around participation or a lack of it and a constituency to leverage change (Flores 2010):

- 2007-Capture demands for participatory methods within the innovation systems and organize the methods to meet that demand.

- 2008-Promote the use of participatory methods according to the demand for them and evaluate their outcomes and impacts.

- 2009-Improve the participatory methods.

- 2010-Use the evidences of the outcomes and impacts for policy advocacy to enable participatory research and improve its quality and relevance.

Advocacy was driven by evidence that the inclusion of smallholders in development research-\&-development improved the interventions (Flores 2010).

From 2007 to 2009 the Andean Change Alliance facilitated the use of and evaluated participatory approaches, including eight cases of the PMCA in Peru, Bolivia, Ecuador, and Colombia (Table 13.1) (Devaux et al. this volume). Andean Change provided training, backstopping, and coaching.

Local teams consistently sought to adapt PMCA to fit local circumstances; respecting to different degrees the PMCA's fundamental principles. However, in Santa Cruz, Bolivia during a fruit PMCA and a vegetable PMCA, the facilitators tried to rush the model by skipping phase 2, and farmers rejected the contract offered to them because they had not built up enough trust with the buyer. 
Table 13.1 Eight cases of PMCA in the Andes, facilitated by the Andean Change Alliance

\begin{tabular}{|c|c|c|c|c|}
\hline Case & New product & $\begin{array}{l}\text { Completed } \\
\text { PMCA }\end{array}$ & Analyzed $^{\mathrm{a}}$ & Deviations/problems \\
\hline $\begin{array}{l}\text { 1. Coffee/ } \\
\text { Peru }\end{array}$ & $\begin{array}{l}\text { Roasted coffee, } \\
\text { packaged and } \\
\text { labeled }\end{array}$ & Yes & Yes & \\
\hline $\begin{array}{l}\text { 2. Cheese/ } \\
\text { Bolivia }\end{array}$ & $\begin{array}{l}\text { Mozzarella packed } \\
\text { for retail market }\end{array}$ & Yes & Yes & $\begin{array}{l}\text { NGO had low interest in creating } \\
\text { links with other market actors }\end{array}$ \\
\hline $\begin{array}{l}\text { 3. Potatoes/ } \\
\text { Bolivia }\end{array}$ & $\begin{array}{l}\text { Native varieties in } \\
\text { net bags for } \\
\text { supermarket }\end{array}$ & Yes & Yes & $\begin{array}{l}\text { NGO had low interest in } \\
\text { developing new market products } \\
\text { and links }\end{array}$ \\
\hline $\begin{array}{l}\text { 4. Yams/ } \\
\text { Colombia }\end{array}$ & No & Yes & Yes & $\begin{array}{l}\text { Outside knowledge had less to } \\
\text { offer }\end{array}$ \\
\hline $\begin{array}{l}\text { 5. Potatoes/ } \\
\text { Ecuador }\end{array}$ & Semi-formal seed & Yes & No & $\begin{array}{l}\text { Tried to work at national scale } \\
\text { immediately. Consumers had less } \\
\text { interest in native potatoes }\end{array}$ \\
\hline $\begin{array}{l}\text { 6. Cheese/ } \\
\text { Peru }\end{array}$ & No & No & No & $\begin{array}{l}\text { Facilitators stressed a new } \\
\text { production technology, not } \\
\text { market innovation }\end{array}$ \\
\hline $\begin{array}{l}\text { 7. Fruit/ } \\
\text { Bolivia }\end{array}$ & No & No & No & $\begin{array}{l}\text { Facilitators skipped phase } 2 \text { of } \\
\text { PMCA }\end{array}$ \\
\hline $\begin{array}{l}\text { 8. Veg/ } \\
\text { Bolivia }\end{array}$ & No & No & No & Same as above \\
\hline
\end{tabular}

a.e. discussed by Horton et al. (2013)

Horton et al. (2013) focused on four completed cases. Results were greatest where PMCA was implemented with the greatest fidelity. Most important is the engagement of market actors, not just farmers. Adapting a method (lack of fidelity) may be innovative, but if local teams are encouraged to change any and all parts of the model they may skip key components (Horton et al. 2013).

The analysis and documentation of experience with the implementation of SEP and CIALs showed positive outcomes related to the agency of farmers and farmer organizations with enhanced self-respect of farmers, mutual respect among different actors, enhanced capacity for negotiation and stronger organizations. The enhanced agency of farmers promoted structural changes that affected local traditional organizations and development institutions. Institutional innovation, changes in rules, roles, and practices involving power sharing occurred initially at the local organizational level and gradually permeated into the institutional level reaching practices and processes in the institutions that delivered the services (Polar et al. 2012). There were positive changes in the quality of agricultural advisory services as well as in coverage and inclusion. However, farmers' agency was still unable to generate institutional changes in public sector actors (Polar 2014).

Perhaps the furthest reaching, and longest lasting advocacy of the Andean Change Alliance was with the many national organizations, public and civil, which participated with farmers in research, commissioned and mentored by the Alliance (Thiele et al. 2012; Flores 2010). 


\subsubsection{Nutrition-Related Participatory Research Through Potato}

In a cruel irony, people who spend much of their day producing food are often unable to properly feed their own kids. The children of many Andean farm families are chronically undernourished. The causes and contexts of poverty and a poor diet are complex. Nonetheless, in about 2010, CIP crop scientist André Devaux and colleagues, in line with government diagnosis, recognized that anemia is a major problem which research could tackle. In the Andes over $20 \%$ of children under three suffer from chronic undernourishment, mainly due to deficiencies of micro elements such has iron and zinc; $39 \%$ of children under two are anemic (Devaux et al. 2015).

Anemia can result from a diet poor in zinc and iron. Fortunately, some native potato varieties are rich in zinc and iron, and the vitamin $\mathrm{C}$ in potatoes helps to body to absorb these essential minerals. Potatoes are also well endowed with vitamin B, antioxidants, and have as much protein as grains, so a diet with generous portions of native potatoes can be nutritious (Devaux et al. 2012; Ordinola 2015; CreedKanashiro et al. 2015).

From 2011 to 2015, Devaux and colleagues led a project, IssAndes (Innovation for food security and sovereignty in the Andes) to address undernutrition with research. IssAndes started with a baseline study in rural communities in Apurímac and Huancavelica, Peru. The results confirmed that $42 \%$ of children under 2 years of age where chronically undernourished. Fifty-four percent of the children were not getting enough iron in their diets and zinc was deficient in 48\% (Creed-Kanashiro et al. 2014). The baseline study also found a positive relationship between children's iron and zinc intake with native potato production, raising small animals, and area of production (Creed-Kanashiro et al. 2015). Area of production would correlate with household income, suggesting that better-off families could feed their children a more diverse diet.

Building on the work of plant breeders, Devaux and colleagues identified 200 native potato varieties in the CIP genebank with high levels of zinc and iron. The next step was to see which of those varieties would appeal to farm families. This was somewhat like the previous work with PMCA (see Sect. 13.2.5), but then the emphasis had been on finding potatoes of the right size, shape, color, and taste to appeal to the gourmet food market in Lima. Now, the goal was to find nutritious potato varieties for the poor (Devaux and Kromann 2016). Farmers in the highland communities participated in assessing CIP's improved clones from a breeding population that resembled native varieties using PVS (see Sect. 13.2.4) and selected one particular variety. This appealing variety was named "Kawsay" (Quechua for "to live"). The Peruvian government released Kawsay, as mentioned in Sect. 13.2.4, as a resistant variety with higher content of iron and zinc.

Since the baseline study had suggested that higher incomes led to healthier children (Creed-Kanashiro et al. 2015), IssAndes worked to improve livelihoods by helping farm families to create something to sell. The project helped to launch 
Kiwa ${ }^{\circledR}$ nutritious: colored potato chips, made from native potatoes and sold around the world (Devaux and Kromann 2016).

Through IssAndes, over 5000 rural farm households in Peru, Bolivia, Ecuador, and Colombia, were encouraged to grow, eat, and sell native potatoes rich in zinc and iron, and to experiment with vegetable home gardens and with raising guinea pigs and other small animals.

\subsection{The Prospects of PR in the Andes and Globally}

The previous sections of the chapter have described different PR stages and approaches used by CIP over the last three decades, which has shown to be a valuable mechanism to bring together different stakeholders to develop technologies, methodological approaches, and business opportunities. It has been observed that at the beginning of CIP's PR experience, the types of actors involved in agricultural research for development were relatively few (farmers, extension workers, and researchers, mostly from government organizations), but the range of new stakeholders started to increase over the years, including NGOs, farmer organizations, civil society, and private sector. New PR methods such as the PMCA evolved to include the views of these diverse actors; but within a single value chain and for particular business opportunities. However, agri-food systems are becoming more complex with interconnectedness established from rural to urban areas and vice versa, and future PR approaches will need to take this into account. Therefore, methods will need to continue evolving to deal with increasingly complex agricultural innovation systems (Hall et al. 2004; Ortiz et al. 2013; Hellin 2012) to face emerging challenges, such as climate change. In addition, the ways in which farmers are connected to the world is also changing.

The penetration of information and communication technologies (ICTs) to rural areas has increased significantly in recent years, opening new opportunities for capturing farmers' views in ways not attempted before. In the developed world, farmers are already immersed in extensive and complex networks of information sharing and decision support tools facilitated by ICTs; and although in developing countries, this is not yet the case, ICTs can facilitate gathering the opinions of more farmers, and also diverse actors in the value chains, and to share those views with actors located in other regions and countries. In addition, farmers in developing countries are slowly moving towards being part of the big data movement, which will connect information in new and faster ways. For example, farmer preferences differentiated by gender could be linked with the genetics that explain those traits, making it possible to establish a connection between trait preferences and trait genetics in a way that was not possible before.

Adaptation and resilience to climate change requires farmers to adapt faster than even before, for which the flow of information from and to them should also be faster. ICTs offer the possibility of connecting a larger number of farmers with sources of information and advice that could help them to make decisions to tackle 
climate change-CIP already experimented with this (Sperling et al. 2008), but in the future, there will be the need to connect even more people with more information sources, and, particularly, to support making sense of the available big data for farmers' decision making.

The essence of PR approaches has been maintained over the years as a mechanism to facilitate the dialogue between scientists from different disciplines, and particularly between them and farmers or other actors of the value chain. This will continue evolving and in the future, PR methods will need to include a larger number of viewpoints, from the disciplinary view point, but also from the innovation and agri-food systems viewpoints, and new ICTs offer the possibility of improving communication, analysis, and decision making. We can envision a larger number of PVS using mother and baby trials, all interconnected in real time, so that farmer groups not only analyze their own results, but access results of many more, and also breeders can provide the genetic explanation of user preferences. The future is full of opportunities for PR.

\subsection{Concluding Remarks}

The early experience with participatory research at CIP, with farmer-back-to-farmer in the early 1980s, showed the importance of identifying research topics with farmers, working with communities creatively, and presenting results back to farmers. These ideas informed much of the later participatory research at CIP and elsewhere (Thiele et al. 2001).

By the early 1990s, social scientists were accepted as full team members of research teams. Research methods were more formal, unlike farmer-back-to-farmer with its "loose guidelines rather than polished and elaborate research methods" (Thiele et al. 2001). The Pilot Areas approach now measured results with economic impact (Ortiz et al. 2009), which allowed evaluating several technologies at once.

The IPM research (Pilot Areas and FFS) showed the importance of understanding gaps in farmers' knowledge and sharing ideas with them to further collaboration. By the late 1990s, FFS became a formal research method at CIP. FFS and PVS (mother-and-baby) started at about the same time and were influenced by motherand-baby trials at CIMMYT and work by CIP with "friendly" varieties (Prain et al. 1992).

The Pilot Areas had started working with NGOs. FFS and PVS continued to collaborate with NGOs, but with PVS the NGOs were incorporated into larger consortia, with more forming training and workshops for staff. Food manufacturers, wholesalers, restaurants, and the rest of the value chain were brought into research.

In the early 2000s, the PMCA involved other market chain actors, besides farmers. With PMCA it was no longer enough to select a new variety or a technology: PMCA stimulates innovations by actors. PMCA contributed to a progressive shift in consumers' perceptions of native potato varieties to reposition them as prestigious, even gourmet food, and improving livelihoods. 
In the 2010s, the Alliance for Andean Change explicitly intended to promote broader uptake of PMCA, PVS, Participatory Monitoring and Evaluation, and other participatory methods, validating them in four Andean countries and using the evidence of success to advocate for the mainstreaming of participatory methods with national research systems. It was not possible to document the influence of Andean Change on national systems, because the project ended prematurely, but there may have been a lasting influence on many partner organizations in Peru, Bolivia, Ecuador, and Colombia.

By 2012, multidisciplinary research linked with CIP plant breeding which provided native varieties with high zinc and iron content. These varieties were then evaluated with farmers, using techniques refined by previous work with PVS. The nutrition research followed on the successful work with PMCA, but now the emphases was not on finding a more marketable potato, but on choosing a more nutritious one. Like the Andean Change Alliance, the nutrition work with the Iss Andes project collaborated with 20 organizations in four Andean countries (actually, many of the same organizations that had been part of Andean Change). INIAP, the government agricultural research institute in Ecuador, built a large aeroponics unit devoted in part to producing seed of native potato varieties. This can be seen as an example of successful advocacy from Andean Change and previous CIP work (e.g. with PVS).

While participatory research at CIP may seem fragmented and at times uncertain (Thiele et al. 2001), CIP never stopped using participatory research. CIP social scientists, breeders, IPM specialists and agronomists have continued working together, innovating, creating influential participatory methods that integrate disciplines, bring farmers on board, and widen participation to include all the actors of the value chain, which in the future will continue evolving to face more complex challenges and link more diverse stakeholders taking advantage of emerging technologies (ITCs) and the possibility of using the big data revolution.

\section{References}

Allauca Saguano SM (2011) Análisis de los criterios de preferencias en la selección de nuevas variedades de papa, con enfoque en la influencia del mercado. Thesis, Universidad Nacional Agraria, La Molina, Lima, Peru, 239 p

Arcos J, Gastelo M, Holguín V (2015) INIA 317 - Altiplano, variedad de papa con buena adaptación en la región altiplánica del Perú. Revista Latinoamericana de la Papa 19(2):68-75

Bernet T, Thiele G, Zschocke T (2006) Participatory market chain approach (PMCA) — user guide. International Potato Center (CIP) - Papa Andina, Lima

Camacho-Henriquez A, Kraemer F, Galluzzi G, de Haan S, Jäger M, Christinck A (2015) Decentralized collaborative plant breeding for utilization and conservation of neglected and underutilized crop genetic resources. In: Al-Khayri JM, Jain SM, Johnson DV (eds) Advances in plant breeding strategies: breeding, biotechnology and molecular tools, vol 1. Springer, Heidelberg, pp 25-61

Chiri A, Ccama F, Fano H, Dale W (1997) Final evaluation of the integrated pest management for Andean Communities (MIPANDES) project (no. 527-0372). Report submitted to CARE/Peru

CIP (2014) Liberan nueva variedad de papa 'INIA 325 - PODEROSA' en Perú. https://cipotato. org/es/press-room/blog/liberan-nueva-variedad-papa-inia-325-poderosa-peru/. Accessed 9 Aug 2017 
Cisneros F, Alcázar J, Palacios M, Ortiz O (1995) A strategy for developing and implementing integrated pest management. CIP Circular 21(3):2-7

Creed-Kanashiro HM, Astete-Robilliard L, Abad Arrue M, Marin M, Bartolini R (2014) Línea de Base Nutricional Perú. Proyecto IssAndes. CIP, Lima, p 65

Creed-Kanashiro H, Hareau G, Devaux A, Maldonado L, Ordinola M, Fonseca C, Suarez V, Astete L, Marin M, Penny M (2015) Agriculture-nutrition linkages: nutritional outcomes in potato based production systems of Peru. Poster presented at the conference on global food security

De Haan S, Salas E, Fonseca C, Gastelo M, Amaya N, Bastos C, Hualla V, Bonierbale M (2017) Selección participativa de variedades de papa (SPV) usando el diseño mamá y bebé: una guía para capacitadores con perspectiva de género. CIP, Lima, $82 \mathrm{p}$

Devaux A, Kromann P (2016) Strengthening innovation in agri-food systems for food security in the Andes. CIP, Lima, 2 p

Devaux A, Horton D, Velasco C, Thiele G, López G, Bernet T, Reinoso I, Ordinola M (2009) Collective action for market chain innovation in the Andes. Food Policy 34(1):31-38

Devaux A, Andrade-Piedra J, Ordinola M, Velasco C, Hareau G, López G, Rojas A, Flores P, Fonseca C, Kromann P (2012) Agricultura, seguridad alimentaria y nutrición en los Andes: potenciales aportes de la innovación en papa. Paper read at the Congreso de la Asociación Latinoamericana de la Papa, 17-20 Sep 2012, Uberlândia, Brazil

Devaux A, Flores P, Velasco C, Babini C, Ordinola M (2015) Innovation to enhance agriculture, nutrition, and health linkages. IssAndes project brief. International Potato Center, Lima, $6 \mathrm{p}$

Engel P, Salomon M (2003) Facilitating innovation for development: a RAAKS resource box, Amsterdam

Flores R (2010) Avances, oportunidades y temas estratégicos de incidencia política en la región. Paper read at the Taller de Evidencias y Argumentos, Metodologías de la Alianza Cambio Andino y Metodologías Invitadas. Cambio Andino, Lima, 8-10 Nov 2010

Fonseca C, De Haan S, Miethbauer T, Maldonado L, Ruiz R (2011) Selección participativa de variedades de papa en Perú. In: Thiele G, Quirós CA, Ashby J, Hareau G, Rotondo E, López G, Paz Ybarnegaray R, Oros R, Arévalo D, Bentley J (eds) Métodos participativos para la inclusión de los pequeños productores rurales en la innovación agropecuaria: experiencias y alcances en la región andina 2007-2010. Programa Alianza Cambio Andino, Lima, pp 169-184

Godtland E, Sadoulet E, de Janvry A, Murgai R, Ortiz O (2004) The impact of farmer-field-schools on knowledge and productivity: a study of potato farmers in the Peruvian Andes. Econ Dev Cult Change 53:63-92

Hall A, Mytelka L, Oyeyinka B (2004) Innovation systems: what's involved for agricultural research policy and practice? ILAC brief 2

Hellin J (2012) Agricultural extension, collective action and innovation systems: lessons on network brokering from Peru and Mexico. J Agric Educ Exten 18(2):141-159

Heong KL, Escalada MM, Chien HV, Cuong LQ (2014) Restoration of rice landscape biodiversity by farmers in Vietnam through education and motivation using media. Surv Perspect Integr Environ Soc 7(2)

Horton D (1986) Farming systems research: twelve lessons from the Mantaro Valley Project. Agric Admin 23:93-107

Horton D, Samanamud K (2013) Peru's native potato revolution. Papa Andina innovation brief 2. International Potato Center, Lima, $6 \mathrm{p}$

Horton D, Rotondo E, Paz Ybarnegaray R, Hareau G, Devaux A, Thiele T (2013) Lapses, infidelities, and creative adaptations: lessons from evaluation of a participatory market development approach in the Andes. Eval Program Plann 39:28-41

Janampa Martínez AM (2012) Selección participativa bajo el diseño mamá \&bebé de 20 clones de papa Solanum tuberosum spp. andígena (población B1C5), con resistencia horizontal a la rancha (Phytophthora infestans). Thesis, Universidad para el Desarrollo Andino, Lircay, Huancavelica, Peru, $127 \mathrm{p}$

Kromann P, Montesdeoca F, Andrade-Piedra J (2016) Integrating formal and informal potato seed systems in Ecuador. In: Andrade-Piedra J, Bentley J, Almekinders C, Jacobsen K, Walsh S, Thiele G (eds) Case studies of root, tuber and banana seed systems. RTB working paper no. 2016-3. RTB, Lima, pp 13-32 
Nelson R, Orrego R, Ortiz O, Tenorio J, Mundt C, Fredrix M, Vien NV (2001) Working with resource-poor farmers to manage plant diseases. Plant Dis 85(7):684-695

Ordinola M (2015) Agricultura, nutrición y seguridad alimentaria: un enfoque diferente. Agro Enfoque 199:65-67

Ordinola M, Devaux A, Bernet T, Manrique K, Lopez G, Fonseca C, Horton D (2014) The PMCA and potato market chain innovation in Peru. Papa Andina innovation brief 3. International Potato Center, Lima, $8 \mathrm{p}$

Oros R, Rodríguez F, Gonzales F, Thiele G (2011) Caso de implementación EPCP 2: la papa nativa en Norte Potosí, Bolivia. In: Thiele G, Quirós CA, Ashby J, Hareau G, Rotondo E, López G, Paz Ybarnegaray R, Oros R, Arévalo D, Bentley J (eds) Métodos participativos para la inclusión de los pequeños productores rurales en la innovación agropecuaria: experiencias y alcances en la región andina 2007-2010. Programa Alianza Cambio Andino, Lima, pp 99-109

Orrego R, Ortiz I, Tenorio J (2010) Interactuando para aprender: el caso de las escuelas de campo de agricultores (ECAs) en el Perú. LEISA 26(4):33-35

Ortiz O (2006) Evolution of agricultural extension and information dissemination in Peru: an historical perspective focusing on potato-related pest control. Agric Human Values 23(4):477-489

Ortiz O, Alcazar J, Palacios M (1997) La enseñanza del manejo integrado de plagas en el cultivo de papa: la experiencia del CIP en la Zona Andina del Perú. 9/10:1-22

Ortiz O, Garret KA, Heath JJ, Orrego R, Nelson RJ (2004) Management of potato late blight in the Peruvian highlands: evaluating the benefits of farmer field schools and farmer participatory research. Plant Dis 88(5):565-571

Ortiz O, Frias G, Ho R, Cisneros H, Nelson R, Castillo R, Orrego R, Pradel W, Alcázar J, Bazán M (2008) Organizational learning through participatory research: CIP and CARE in Peru. Agric Human Values 25(3):419-431

Ortiz O, Kroschel J, Alcázar J, Orrego R, Pradel W (2009) Evaluating dissemination and impact of IPM: lessons from case studies of potato and sweet potato IPM in Peru and other Latin American countries. In: Peshin R, Dhawan AK (eds) Integrated pest management: dissemination and impact. Springer, New York, pp 419-434

Ortiz O, Orrego R, Pradel W, Gildemacher P, Castillo R, Otiniano R, Gabriel J, Vallejo J, Torres O, Woldegiorgis G, Damene B, Kakuhenzire R (2011) Incentives and disincentives for stakeholder involvement in participatory research (PR): lessons from potato-related PR from Bolivia, Ethiopia, Peru and Uganda. Int J Agric Sustain 9(4):522-536

Ortiz O, Orrego R, Pradel W, Gildemacher P, Castillo R, Otiniano R, Gabriel J, Vallejo J, Torres O, Woldegiorgis G, Damene B, Kakuhenzire R, Kasahija I, Kahiu I (2013) Insights into potato innovation systems in Bolivia, Ethiopia, Peru and Uganda. Agric Syst 114(2013):73-83

Ortiz O, Nelson R, Olanya M, Thiele G, Orrego, R, Pradel W, Kakuhenzire R, Woldegiorgis G, Gabriel J, Vallejo J, Xie, K (2019) Human and Technical Dimensions of Potato Integrated Pest Management Using Farmer Field Schools: International Potato Center and Partners' Experience With Potato Late Blight Management. Journal of Integrated Pest Management 10(1):1-8

Parsa S (2010) Native herbivore becomes key pest after dismantlement of a traditional farming system. Am Entomol 56(4):242-251

Polar V (2014) Participation for empowerment: an analysis of agricultural innovation in two contrasting settings of Bolivia. PhD thesis. School of Oriental and African Studies, University of London, 331 p, La Paz - SOAS. http://eprints.soas.ac.uk/20311/1/Polar_Funez_3625.pdf

Polar V, Fernández J, Ashby J, Quiros CA, Roa JI (2012) Participatory methods and the coproduction of agricultural advisory services. Results from four case studies in Bolivia and Colombia. International Potato Center (CIP), Lima. Working paper 2012-1, 107 p. https:// cgspace.cgiar.org/bitstream/handle/10568/90952/CIP-Participatory-methods-and-the-coproduction-of-agricultural-advisory.pdf?sequence $=1$

Prain G, Uribe F, Scheidegger U (1992) "The friendly potato": farmer selection of potato varieties for multiple uses. In: Moock JL, Rhoades RE (eds) Diversity, farmer knowledge and sustainability. Cornell University Press, Ithaca, pp 52-68

Pumisacho M, Sherwood S (2000) Herramientas de aprendizaje para facilitadores: manejo integrado del cultivo de papa. INIAP, CIP, FAO, Quito 
Rhoades R (1987) Farmers and experimentation. ODI AgREN discussion paper 21

Rhoades RE, Booth RH (1982) Farmer-back-to-farmer: a model for generating acceptable agricultural technology. Agric Admin 11(2):127-137

Rhoades RE, Horton DE, Booth RH (1986) Anthropologist, biological scientist and economist: the three musketeers or three stooges of farming systems research. In: Jones JR, Wallace BJ (eds) Social sciences and farming systems research. Methodological perspectives on agricultural development. Westview, Boulder, pp 21-40

Sherwood S, Nelson R, Thiele G, Ortiz O (2000) Farmer field schools for ecological potato production in the Andes. LEISA-Leusden 16:24-25

Sineace (National System for Evaluation, Accreditation and Certification of Educational QualityMinistry of Education, Peru) (2016) Facilitadores de Escuelas de Campo de Agricultores podrán certificar sus competencias. https://www.sineace.gob.pe/facilitadores-de-escuelas-decampo-de-agricultores-podran-certificar-sus-competencias/. Accessed 11 Jan 2018

Snapp S (1999) Mother and baby trials: a novel trial design being tried out in Malawi. TARGET. The newsletter of the Soil Fertility Research Network for Maize-Based Cropping Systems in Malawi and Zimbabwe. January 1999 issue. CIMMYT, Harare

Snapp S (2002) Quantifying farmer evaluation of technologies: the mother and baby trial design. In: Bellon MR, Reeves J (eds) Quantitative analysis of data from participatory methods in plant breeding. CIMMYT, Mexico City, pp 9-17

Sperling F, Validivia C, Quiroz R, Valdivia R, Angulo L, Seimon A, Noble I (2008) Transitioning to climate resilient development: perspectives from communities in Peru, Environment department papers, no.115. Climate change series. Washington, DC, World Bank, 103p

Thiele G, van de Fliert E, Campilan D (2001) What happened to participatory research at the International Potato Center? Agric Human Values 18:429-446

Thiele G, Devaux A, Reinoso I, Pico H, Montesdeoca F, Pumisacho M, Andrade-Piedra J, Velasco C, Flores F, Esprella R, Thomann A, Manrique K, Horton D (2011) Multi-stakeholder platforms for linking small farmers to value chains: evidence from the Andes. Int J Agric Sustain 9(3):423-433

Thiele G, Quirós CA, Ashby J, Hareau G, Rotondo E, López G, Paz Ybarnegaray R, Oros R, Arévalo D, Bentley J (eds) (2012) Métodos participativos para la inclusión de los pequeños productores rurales en la innovación agropecuaria: experiencias y alcances en la región andina 2007-2010. Programa Alianza Cambio Andino, Lima. https://cgspace.cgiar.org/handle/10568/65712

Veteto JR, Crane TA (2014) Tending the field: special issue on agricultural anthropology and Robert E. Rhoades. Cult Agric Food Environ 36(1). https://doi.org/10.1111/cuag.12023

Open Access This chapter is licensed under the terms of the Creative Commons Attribution 4.0 International License (http://creativecommons.org/licenses/by/4.0/), which permits use, sharing, adaptation, distribution and reproduction in any medium or format, as long as you give appropriate credit to the original author(s) and the source, provide a link to the Creative Commons license and indicate if changes were made.

The images or other third party material in this chapter are included in the chapter's Creative Commons license, unless indicated otherwise in a credit line to the material. If material is not included in the chapter's Creative Commons license and your intended use is not permitted by statutory regulation or exceeds the permitted use, you will need to obtain permission directly from the copyright holder.

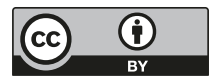

